(C).О. Налобіна, д.т.н.

Національний університет водного господарства та природокористування

О.П. Герасимчук, к.т.н.

Луцький національний технічний університет

\title{
АНАЛІЗ ФАКТОРІВ ВПЛИВУ НА ВЕЛИЧИНУ ЗІБРАНОЇ ПЛОЩІ КОНОПЛІ
}

У статті викладено методику оцінювання зібраної площі коноплі за певний проміжок часу з врахуванням факторів, які впливають на збиральний процес. Представлено графічні 
залежності зібраної плоші від часу, які придатні до практичного використання з метою контролю протікання процесу збирання та коригувати його виконання для уникнення втрат $i$ підвищення продуктивності робіт.

Постановка проблеми. Конопля володіють потужним економічним та екологічним потенціалом. Це $\epsilon$ одна 3 найважливіших культур, які здатні рекультивувати забруднені й виведені 3 обороту землі шляхом виведення 3 грунту отруйних домішок. Із конопель можна виготовити до п’ятдесяти тисяч різноманітних виробів (рис.1).

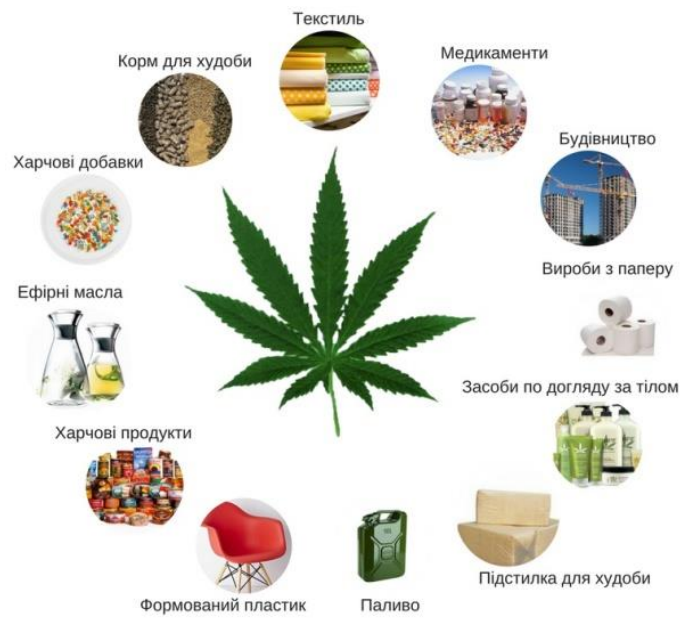

Рис. 1 - Сфера застосування технічної коноплі

3 коноплі виготовляють прядильні волокна, канати, шпагат, рибальські сіті, спецодяг, брезент, парусину, мішковину, пожежні рукави, канати, шпагат, цінний папір. Із насіння отримують олію, 3 якої виробляють оліфу, рідке мило, замазку, лаки, фарби та ін. Рафінована конопляна олія використовується в харчовій промисловості. Насіннєва макуха завдяки великому вмісту поживних речовин є однією 3 найкращих добавок до корму для худоби.

Тканини 3 луб'яних волокон володіють унікальними властивостями. Зокрема, ці тканини є антистатичними, гігієнічними, поглинають до 30\% поту і 95\% ультрафіолетових променів. Вони забезпечують комфортну температуру і вологість простору під одягом за одночасного видалення поту з поверхні тіла. 
Одяг із таких тканин рекомендується щоденно носити людям, схильним до захворювань ревматизмом, алергією шкіри, хворобам хребта [1].

Посівні площі під коноплі в Україні в 2008 і 2010 роках складали: відповідно - 910 і 820 га [2, 3]. В останні роки посівні площі під коноплями в Україні значно скоротилися через високу праце- та енергомісткість галузі (рис. 2). За площами посіву конопель Україна суттєво відстає від багатьох економічно розвинутих країн Свропи.

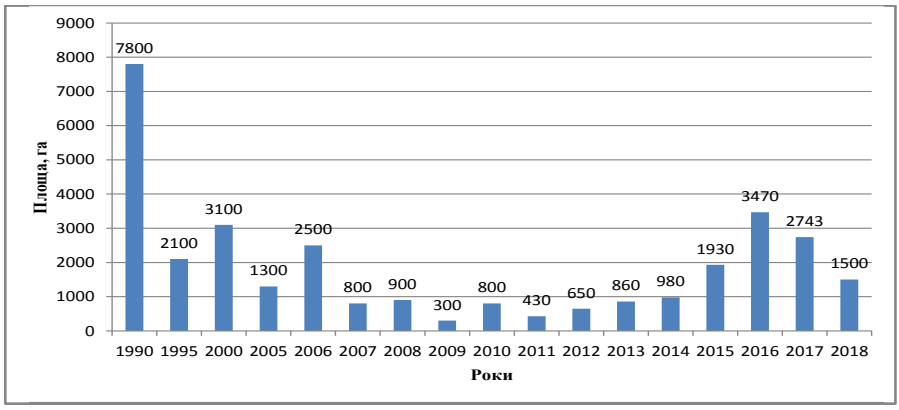

Рис. 2 - Динаміка посівних площ під коноплю в Україні

Найбільш трудомістким процесом під час вирощування конопель є збирання. Застосування сільськогосподарських машин загального призначення (зернозбиральних комбайнів, роторних граблів, прес-підбирачів), що не призначенні для роботи з міцною і довгою волокнистою масою та стеблами коноплі, значно знижує надійність збиральних робіт.

Удосконалення технології збирання коноплі потребує пристосування наявних сільськогосподарських машин загального призначення до особливостей стебел коноплі, а також розробки нових високопродуктивних засобів механізації збиральних робіт, що оріснтовані на виробництво якісної кінцевої продукції. Вирішення цих питань не можливе без всебічного досліджень технологій та технічних засобів, призначених для збирання коноплі.

Сучасні ринкові умови вимагають нових підходів до розроблення технологій та технічних засобів для збирання промислових конопель. Збирання конопель $є$ найвідповідальнішою операцією в технології їі вирощування. Лише за умови правильної організації процесу збирання та дотримання техніко-технологічних вимог до нього можна повністю зберегти вирощений урожай із 
забезпеченням показників якості, зменшити витрати праці, собівартість волокна і насіння та підвищити ефективність галузі коноплярства.

Аналіз останніх досліджень і публікацій. Аналізу сучасних технологій збирання коноплі та удосконаленню процесу збирання присвячено роботи Гілязетдінова Р. Н., Лінника М. К., Макаєва В. І., С. П. Коропченко, О.А. Примакова О. А., І. О. Маринченко [4-8]. Роботи вчених направлені на розробку технічних засобів, які сприяють підвищенню ефективності збирання стебел конопель.

Аналіз чинних досліджень виявив, що аграрна галузь має потенційні можливості та резерви для стабілізації та розвитку коноплярства. Ефективне використання існуючих резервів повинне базуватись на аналізі механізмів формування i функціонування технологічних процесів виробництва продукції коноплярства, аналізі напрямків іiі використання та обгрунтуванні перспективних напрямків розвитку спеціалізованих технічних засобів для збирання коноплі.

Встановлено, що відсутні дослідження експлуатаційних властивостей технічних засобів для збирання конопель, зокрема показника продуктивності виконання збиральних робіт. 3 урахуванням цього сформулюємо мету даної роботи.

Мета дослідження. Проаналізувати фактори які впливають на продуктивність збирання коноплі.

Результати дослідження. Домогтися підвищення продуктивності машинно-тракторних агрегатів та всього парку можна за рахунок комплексного врахування всіх основних діючих чинників.

Перша група чинників має вирішуватися на етапі створення машин. У конструкцію машини повинні бути закладені оптимальні параметри, висока надійність i ремонтопридатність, пристосованість конструкції до проведення технічного та технологічного обслуговування, створення сприятливих умов роботи для обслуговуючого персоналу.

Друга група чинників пов'язана 3 практичним використанням потенційних можливостей агрегатів в процесі їхньої експлуатації. Для цього необхідно забезпечити оптимальне комплектування агрегатів i справний стан робочих органів, відповідність технологічних регулювань умовам і режиму роботи; вибрати найкращий спосіб руху.

Третя група чинників, що забезпечують високу продуктивність, пов’язана з організацією використання машинно- 
тракторних агрегатів: забезпечення швидкої доставки агрегатів і механізаторів до місця роботи і назад, скорочення простоїв машин через очікування обслуговуючих агрегатів і усунення технічних відмов, застосування прогресивних організаційних форм групової роботи агрегатів. Групова робота агрегатів на одному або декількох суміжних ділянках (полях) дозволяє за невеликої кількості технічних засобів механізувати допоміжні роботи, налагодити постачання палива, мастила, організувати підвіз продуктів харчування та доставку механізаторів. Концентрація техніки дозволяє краще організувати їі технічне обслуговування.

Оптимальну кількість агрегатів в групі беруть такою, щоб дотримувалася умова рівності темпу виконання робіт групи до відношенню заданого обсягу робіт на число робочих днів. Це дає можливість скоротити втрати часу на переналагодження i комплектування агрегатів. Впровадження групової роботи агрегатів покращує використання техніки, знижує простої. Велике значення для скорочення непродуктивних втрат часу має організація роботи допоміжних засобів 3 обслуговування агрегатів, які виконують основну роботу. Потрібна кількість допоміжних агрегатів (транспортних засобів для технологічних перевезень, заправників, завантажувачів і т.д.) розраховують з умови поточності виконання робіт.

Під час збиральних робіт агрегати часто працюють на декількох полях, які різняться урожайністю, грунтовими умовами, часом визрівання та засміченістю. Залежно від цих даних i агротехнічного терміну збирання відбувається завантаження агрегату. Аналіз літературних джерел показав, що це явище мало досліджене i потребує більш детального розгляду. Будемо в розрахунках використовувати відому за літературними даними [9] формулу для визначення продуктивності агрегату:

$$
W=0.1 B \cdot v_{M},
$$

де $W$ - продуктивність агрегату за годину роботи, га/год; $B$ ширина захвату агрегату, м; $v_{M}$ - швидкість руху агрегату під час роботи, км/год.

Зібрану площу $S$ за час чистої роботи $t_{P}$ (в годинах) визначимо за умови, що ширина $B$ захвату агрегату та швидкість $v_{M}$ протягом деякого часу $t$ не змінювались:

$$
S=0.1 B \cdot v_{M} \cdot t_{P}
$$

У загальному випадку параметри $B$ i $v_{M}$ можуть змінюватися, але ширина $B$ змінюється у невеликих межах, тому 
можна вважати, що $B \approx$ const ; швидкість $v_{M}$ може бути різною на різних ділянках поля.

3 метою спрощення розрахунків будемо вважати, що агрегат рухається полем зі швидкістю, яка $є$ середньою між вказаними вище швидкостями. Позначимо середню швидкість $v_{M . c}$. Тоді з урахуванням (2), маємо:

$$
S \approx 0.1 B \cdot v_{M . c} \cdot t_{P} .
$$

Час чистої роботи $t_{P}$ залежить від погодних умов, стану грунту, врожайності і засміченості поля. Крім того, агрегат періодично зупиняється через потребу технічного обслуговування або ремонту. 3 урахуванням цього, час $t_{P}$ представимо у вигляді: $t_{P}=t(1-\alpha)$, де $\alpha-$ коефіцієнт, що враховує вплив вище перелічених факторів на час роботи агрегату.

Слід зауважити, що визначення коефіцієнту $\alpha$ має певні труднощі, через невизначеність факторів, які він враховує (наперед не можна передбачити погодні умови та інші події). Подамо даний коефіцієнт наступним чином: $\alpha=\alpha_{1}+\alpha_{2}+\alpha_{3}+\alpha_{4}$, де $\alpha_{1}$ коефіцієнт, який враховує тривалість простою агрегату в нічний час; $\alpha_{2}$ - коефіцієнт, який враховує тривалість простою агрегату через несприятливі погодні умови; $\alpha_{3}$ - коефіцієнт, який враховує тривалість простою агрегату через агротехнічні фактори, наприклад, засміченість поля, полеглість стебел; $\alpha_{4}$ - коефіцієнт, який враховує тривалість простою агрегату через потреби в технічному обслуговуванні або ремонті.

Значення коефіцієнтів ми визначили базуючись на даних, щодо довготривалості роботи коноплезбиральних агрегатів у польових умовах протягом двохрічного спостереження за роботою агрегату на полях компанії ТОВ «Фаворит-Агро» (м. Корець, Рівненська область):

$$
\alpha_{1}=0.3-0.365 ; \alpha_{2}=0.178-0.232 ; \alpha_{3}=0.05-0.07 ; \alpha_{4}=0.026-0.053 \text {. }
$$

Коефіцієнт $\alpha_{4}$ за умови правильної організації процесу обслуговування агрегату, наприклад за рахунок проведення профілактичних і ремонтних робіт у час вимушеного простою через несприятливі погодні умови, можливо суттєво зменшити.

3 урахуванням вище викладеного, маємо:

$$
S \approx 0.1 B \cdot v_{M . c} \cdot t_{P}\left(1-\alpha_{1}-\alpha_{2}-\alpha_{3}-\alpha_{4}\right) .
$$


Залежність зібраної площі $S$ від часу $t$ з урахуванням агротехнічного терміну збирання коноплі на одній ділянці, площа якої $S_{1}$, подано на рис. 3. Час збирання зазначеної площі $-t_{1}$.

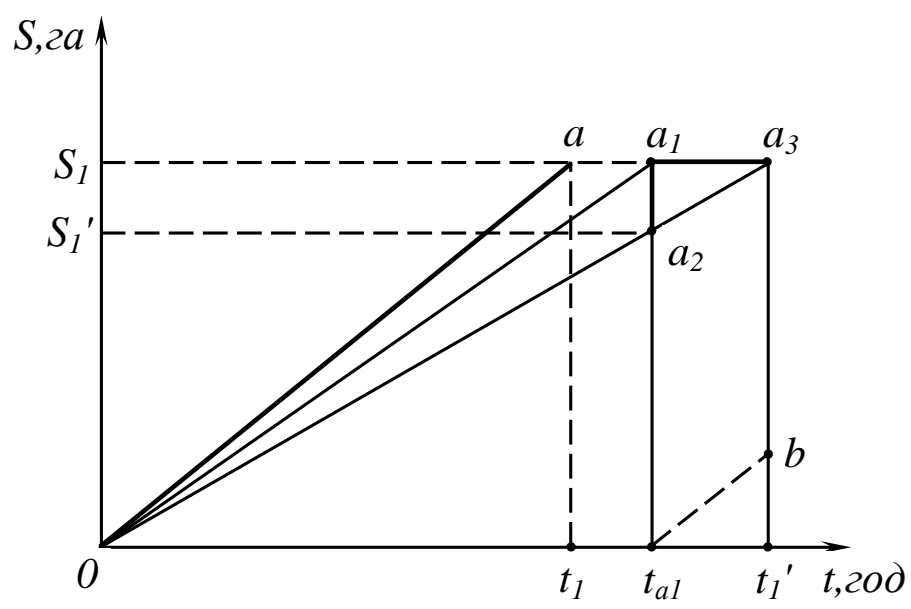

Рис.3 - Формування зібраної площі з плином часу

Добуток $0.1 B \cdot v_{M . c} \cdot\left(1-\alpha_{1}-\alpha_{2}-\alpha_{3}-\alpha_{4}\right)$ позначимо через $K$, тоді $S=K \cdot t_{P} є$ лінійною функцією.

Пряма $O a$ відображує тенденцію зростання зібраної площі за проміжок часу $t_{1}$. За умови, що час $t_{1}$ менший за агротехнічний термін збирання $t_{a 1}$ на осі абсцис час $t_{a 1}$ буде знаходитись праворуч від $t_{1}$ (рис.3). Пряма $O a_{1}$ відображає зростання зібраної площі за умови, що час збирання буде $t_{a 1}$ (співпадає 3 агротехнічним терміном).

На практиці можливим $є$ такий випадок, коли лінія зростання зібраної площі розташовується під лінією $O a_{1}$ (лінія $O a_{2}$ ). У цьому випадку зібрана площа буде менше ніж $S_{1}$ та становитиме $S_{1}^{\prime}$ При цьому відрізок $a_{2} a_{1}$ показує величину незібраної площі $S_{1}-S_{1}^{\prime}$, яку потрібно зібрати за проміжок часу $t_{1}-t_{a 1}$. На графіку (рис. 3) це відповідає точці $a_{3}$, отриманій на перетині продовження прямої $O a_{2} 3$ вертикальною лінією, проведеною з точки $t_{1}^{\prime}$. Відрізок $a_{2} a_{1}$ (або $\left.S_{1}-S_{1}^{\prime}\right) \in$ площею, яка зібрана не в агротехнічний термін, 
внаслідок чого під час їі збирання будуть втрати урожаю. У таких випадках для забезпечення збору урожаю в агротехнічний термін необхідно запустити в роботу ще один збиральний агрегат. Зростання площі збирання урожаю цим агрегатом буде відображатися лінією $t_{a 1} b$.

Так виглядає графічна залежність зібраної площі від часу, за умови, що агрегат працює на одній ділянці поля або на декількох ділянках поля у разі однакових агротехнічних строків збирання. Якщо ж одному агрегату потрібно зібрати декілька ділянок поля 3 різними агротехнічними строками у зв'язку з тим, що вони були засіяні в різні строки або мають різну стиглість, то графік росту зібраної площі буде мати більш складний вигляд порівняно 3 графіком, поданим на рис. 3 .

Покажемо яким чином буде зростати зібрана площа з часом $t$ за таких умов: а) число ділянок, які підлягають збиранню, дорівнює трьом; б) строк закінчення збирання першої ділянки може не співпадати зі строком початку збиральних робіт на другій; в) час збирання може бути меншим або більшим за агротехнічний термін збирання.

Позначимо через $t_{a 1}, t_{a 2}, t_{a 3}$ агротехнічний термін збирання урожаю відповідно на ділянках $1,2,3, t_{I I}$ - проміжок часу між початком збирання першої і другої ділянок; $t_{I I I}-$ проміжок часу між початком збирання другої та третьої ділянок.

Припускаємо, що на рис. 4, а урожай на полі 1 вже достиг i його можна збирати, на полі 2 урожай достигне через час $t_{I I}+t_{I I I}$ від початку збирання. При цьому: $t_{I I} \neq t_{a 1}, t_{I I I} \neq t_{a 2}$.

На кожному полі бажано, щоб агрегат працював не більше агротехнічного строку. Зростання зібраної площі характеризується прямими $O_{1} a, O_{1} a_{1}, O_{1} a_{2}$, але за умови зростання по лінії $O_{1} a_{2}$, частина площі буде зібрана після агротехнічного строку, що веде до втрат врожаю. Тому заростання по прямій $O_{1} a_{2} \epsilon$ небажаним (штрихи на вертикалі $a_{2} a_{2}$, яка опущена 3 точки $a_{2}$ на вісь абсцис, показує, що зростання площі не повинне здійснюватись по прямій $\left.O_{1} a_{2}\right)$.

Зростання зібраної площі другого поля починається в точці $O_{2}^{\prime}$ і може проходити вздовж ліній $O_{2}^{\prime} b, O_{2}^{\prime} b_{1}, O_{2}^{\prime} b_{2} .3$ них зростання вдовж лінії $O_{2}^{\prime} b_{2} \in$ небажаним через можливі втрати. Лінія зростання зібраної площі третього поля починається в точці $O_{3}^{\prime}$ та 
протікає вздовж ліній $O_{3}^{\prime} c, O_{3}^{\prime} c_{1}, O_{3}^{\prime} c_{2}$. Зростання по лінії $O_{3}^{\prime} c_{2} \in$ небажаним.
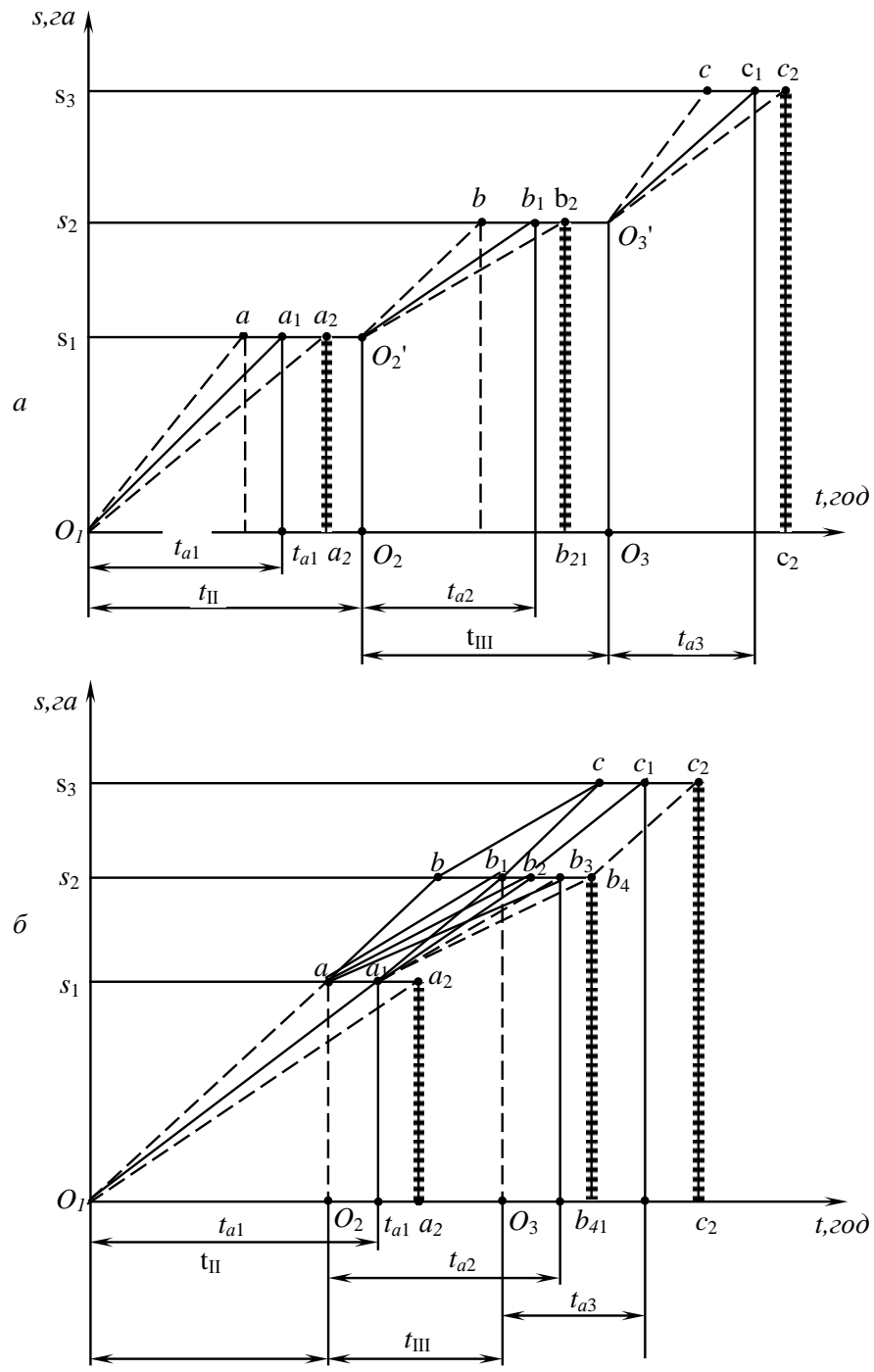

Рис. 4 - Формування зібраної площі з часом: $a$ - агротехнічні строки менші за терміни збирання; $\sigma$ - агротехнічні строки перевищують терміни збирання 
У проміжках часу, коли лінія росту площі не змінюється (горизонтальні ділянки), агрегат простоює.

На рис. 4,6 , розглянуто випадок, коли агротехнічні строки збирання більші за проміжки часу, виділені під збирання окремих ділянок і $t_{a 1}>t_{I I}, t_{a 2}>t_{I I I}$.

Зростання зібраної площі першої ділянки може характеризуватись прямими $O_{1} a, O_{1} a_{1}, O_{1} a_{2}$, при зростанні площі по прямій $O_{1} a$ можливі втрати урожаю. Зростання зібраної площі на другій ділянці здійснюється по лініям $a b, a b_{1}, a b_{2}, a_{1} b_{1}, a_{1} b_{2}, a_{1} b_{3}, a_{1} b_{4}$, Втрати відповідають лінії $a_{1} b_{4}$

Зростання зібраної площі на третій ділянці може протікати по лініях $b_{1} c, b_{2} c, b_{2} c_{1}, b_{2} c_{2}, b_{3} c_{1}, b_{3} c_{2}$, на лінії $b_{2} c_{2}$ маємо втрати врожаю.

3 метою зменшення або унеможливлення втрат та організації збору врожаю у встановлені агротехнічні строки потрібно впроваджувати напрямки збільшення продуктивності агрегату, наприклад шляхом збільшення швидкості його руху. Аналіз конструктивних та кінематичних параметрів збирального пристрою [10], який навішується на трактор, дозволить зробити це авторам у подальшому.

Побудова графіків для різноманітних умов роботи та наступне порівняння їх 3 фактичним станом збиральних робіт агрегату дозволить оперативно вжити заходів, які дозволять уникнути затягування строків збирання і утворення втрат.

Висновки. Запропоновано концепцію прогнозування зібраних площ коноплі на основі якої можна розробити робочі графіки виконання робіт збиральним агрегатом, що придатні до практичного використання 3 метою контролю протікання процесу збирання та коригувати його виконання, а також уникнення втрат $\mathrm{i}$ підвищення продуктивності робіт.

\section{Література}

1. Коноплі : монографія / [Вировець В.Г., Баранник В.Г., Гілязетдінов Р.Н. та ін.] ; за ред. М.Д.Мигаля, В.М.Кабанця. - Суми: Видавничий будинок "Еллада", 2011. - 384 с.

2. Кабанець В.М. Галузі льонарства та коноплярства України: стан та перспективи / В.М. Кабанець // Збірник наукових праць Інституту луб'яних культур УААН. - Вип. 5. - Суми: СОД, 2009. C. 3-7. 
3. Кабанець, В. Ненаркотичні посівні коноплі - культура невичерпних можливостей [Електронний ресурс] - Режим доступу : www.agro-business.com.ua.

4. Гілязетдінов Р. Н. Альтернативне збирання стебел конопель після зернозбирального комбайна / Р.Н. Гілязетдінов, О.А. Примаков, С.П. Соколік // Вісник СНАУ. - Суми, - 2010. Вип. 1(21). - С. 49-52.

5. Лінник, М. К. Нові способи збирання конопель / М.К. Лінник, В.І. Макаєв, О.А. Примаков, І.О. Маринченко // Вісник аграрної науки. - 2010. - № 5. - С. 4851.

6. Патент 47837 UA A01D 91/00. Україна. Спосіб збирання стебел конопель після збирання насіння зернозбиральним комбайном. Макаєв В.I., Примаков О.А., Лук'яненко П.В., Голобородько П.А., Рябченко О.П. № u200909179. Заяв. 07.09.2009; Опубл. 25.02.2010. Бюл. № 4 .

7. Патент 68628 UA A01D 91/00. Україна. Спосіб збирання конопель. Макаєв В. І., Коропченко С.П., Мозоль С.П., Примаков О.А., Довгополий О.М. № 2011 02906. Заявл. 12.03.2011. Опубл. 10.04.2012. Бюл. № 7.

8. Патент 109960 UA A01D 43/10. Україна. Спосіб формування валка зі стебел конопель. Коропченко С.П., Авраменко Є.В., Маринченко І.О., Примаков О.А. № 201511818. Заявл. 30.11.2015. Опубл.26.09.2016. Бюл. № 18 .

9. Експлуатація машин і обладнання: Навчальний посібник / Ружицький М.А., Рябець В.I., Кіяшко В.М. та ін. - К.: Аграрна освіта, 2010. - 617 с.

10. Патент України 116268 UA, МПК A01D 45/06 Пристрій для збирання стебел конопель / О.О. Налобіна, О.П. Герасимчук, С.П. Коропченко, Р.В. Ковальчук; заявник і патентовласник Луцький національний технічний університет. - № u201612654; заяв. 12.12.2016; опубл. 10.05.2017, Бюл. №9. 